\title{
Azaphenanthrene Alkaloids with Antitumoral Activity from Anaxagorea dolichocarpa Sprague \& Sandwith (Annonaceae)
}

\author{
Ana Silvia Suassuna Carneiro Lúcio ${ }^{1}$, Jackson Roberto Guedes da Silva Almeida ${ }^{2}$, \\ José Maria Barbosa-Filho ${ }^{1}$, João Carlos Lima Rodrigues Pita ${ }^{1}$, \\ Marianna Vieira Sobral Castello Branco ${ }^{1}$, Margareth de Fátima Formiga Melo Diniz ${ }^{1}$, \\ Maria de Fátima Agra ${ }^{1}$, Emidio V.L. da-Cunha ${ }^{1,3}$, Marcelo Sobral da Silva ${ }^{1}$ and \\ Josean Fechine Tavares ${ }^{1, *}$
}

1 Laboratory of Pharmaceutical Technology, Federal University of Paraiba, 58051-900, João Pessoa, PB, Brazil; E-Mails: asilviasuassuna@gmail.com (A.S.S.C.L.); jbarbosa@1tf.ufpb.br (J.M.B.-F.); joaocpita@yahoo.com.br (J.C.L.R.P.); mariannavbs@gmail.com (M.V.S.C.B.); margareth@1tf.ufpb.br (M.F.F.M.D.); agramf@1tf.ufpb.br (M.F.A.); marcelosobral@ltf.ufpb.br (M.S.S.)

2 Academic Collegiate of Pharmaceutical Sciences, Federal University of Sao Francisco Valley, P.O. Box 252, 56306-410, Petrolina, PE, Brazil; E-Mail: jackson.guedes@univasf.edu.br

3 State University of Paraíba, Department of Pharmacy, 58100-000, Campina Grande, PB, Brazil; E-Mail: emidio@1tf.ufpb.br

* Author to whom correspondence should be addressed; E-Mail: josean@1tf.ufpb.br; Tel./Fax: +55-83-3216-7427.

Received: 27 June 2011; in revised form: 26 July 2011/ Accepted: 4 August 2011 / Published: 22 August 2011

\begin{abstract}
Phytochemical investigation of Anaxagorea dolichocarpa Sprague \& Sandwith led to isolation of three azaphenanthrene alkaloids: eupolauramine, sampangine and imbiline 1. Their chemical structures were established on the basis of spectroscopic data from IR, HR-ESI-MS, NMR (including 2D experiments) and comparison with the literature. Sampangine and imbiline 1 are being described in the Anaxagorea genus for the first time. Eupolauramine and sampangine show concentration-dependent antitumoral activity in leukemic cells $\mathrm{K} 562$ with $\mathrm{IC}_{50}$ of 18.97 and $10.95 \mu \mathrm{g} / \mathrm{mL}$, respectively.
\end{abstract}

Keywords: Annonaceae; Anaxagorea dolichocarpa; azaphenanthrene alkaloid; antitumor activity 


\section{Introduction}

The family Annonaceae comprises 135 genera, distributed mainly in the tropical and subtropical regions of the World [1]. Phytochemical studies of the family's species have noted the presence of acetogenins [2,3], alkaloids [4,5] and terpenoids [6], with the predominant class being alkaloid secondary metabolites, especially aporphine alkaloids [7].

The genus Anaxagorea includes about 26 species distributed throughout North, Central and South America [8]. Among the known species, only five (A. dolichocarpa, A. brevipes, A. luzonensis, A. clavata and $A$. prinoides) have been studied phytochemically, from which lignoids [9], xantones [10], flavonoids [11] and alkaloids [12] were isolated.

Anaxagorea dolichocarpa shows a wide geographical distribution, occurring from Costa Rica to Bolivia and in Brazil, in the states of Amapá, Amazonas, Acre, Rondônia, Goiás, Maranhão, Paraíba, Pernambuco, Bahia and Rio de Janeiro. It always grows in humid forests [13]. Previous studies on this species reported the isolation of the aporphine alkaloids anaxagoreine and asimilobine [12], the composition of the fruits' essential oil [14] and an antimicrobial activity test against Staphylococcus aureus [15].

Since there is very little phytochemical literature on this species and as it is potentially a good source of bioactive compounds, we decided to expand its phytochemical investigation. We report here the isolation and chemical characterization of three azaphenanthrene alkaloids: eupolauramine (1), sampangine (2) and imbiline 1 (3) isolated from A. dolichocarpa for the first time. The in vitro antitumor activity of eupolauramine and sampangine was also evaluated.

\section{Results and Discussion}

Phytochemical investigation of Anaxagorea dolichocarpa led to the isolation of three azaphenantrene alkaloids: eupolauramine (1), sampangine (2) and imbiline 1 (3), a unique structural series obtained from the plant (Figure 1). The interesting structure of these compounds, together with their rare occurrence makes the study of their pharmacology and the development of potential synthetic routes to these compounds interesting [16,17]. The structural elucidation of these alkaloids was carried out based on their spectroscopic data, mainly 1D and 2D NMR, and also comparison with the literature data [18-20]. This work reports the first 2D NMR data for eupolauramine (1) and sampangine (2). Compound 1 was previously isolated from the species Eupomatia laurina of the family Eupomatiaceae [20] and is being reported for the first time in the family Annonaceae. Compound 2 has been previously reported from Cananga odorata and Cleistopholis patens, both from the family Annonaceae [16]. Compound 3 was already isolated from Duguetia hadrantha (Annonaceae), Eupomatia laurina and E. bennettii (Eupomatiaceae) [16]. Compounds 2 and 3 are described for the first time as isolated from the genus Anaxagorea. Compound $\mathbf{2}$ holds special interest for its relevant pharmacological activities: antifungal [21], anti-malarial [18], antibacterial [22] antitumoral against HL-60 cells (myeloid acute leukemia) [23] and also against human malignant melanoma cells [18]. 
Figure 1. Alkaloids isolated from Anaxagorea dolichocarpa.

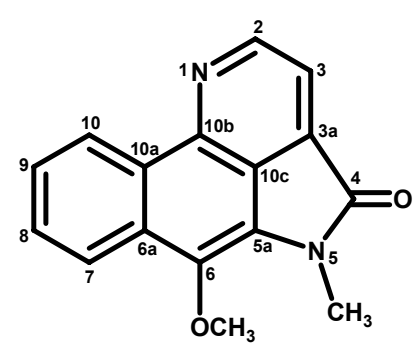

(1)<smiles>O=C1c2ccccc2-c2nccc3ccnc1c23</smiles>

(2)<smiles>COc1c2c3c(ccnc3c3ccccc13)C(=O)C(=O)N2C</smiles>

(3)

The use of natural products as anticancer agents has a long history that began with folk medicine and through the years has been incorporated into allopathic medicine. Many drugs currently used in chemotherapy were isolated from plant species or derived from a natural prototype [24]. The study of natural products represents the most successful strategy for discovering new drugs for anticancer therapy [25].

The in vitro effects of eupolauramine (1) and sampangine (2) against the K562 cell line were determined in three experiments and in quadruplicate (compound 3 could not be tested due to the small amount available). Both compounds exhibited concentration-dependent inhibitory effect on the proliferation of $\mathrm{K} 562$ cells. The $\mathrm{IC}_{50}$ values were $18.97(17.06-21.10) \mu \mathrm{g} / \mathrm{mL}$ and 10.95 $(10.15-11.80) \mu \mathrm{g} / \mathrm{mL}$ respectively, as evaluated by the MTT reduction assay (Figure 2).

Figure 2. Celular viability after the treatment with the alkaloids eupolauramine (A) and sampangine (B).
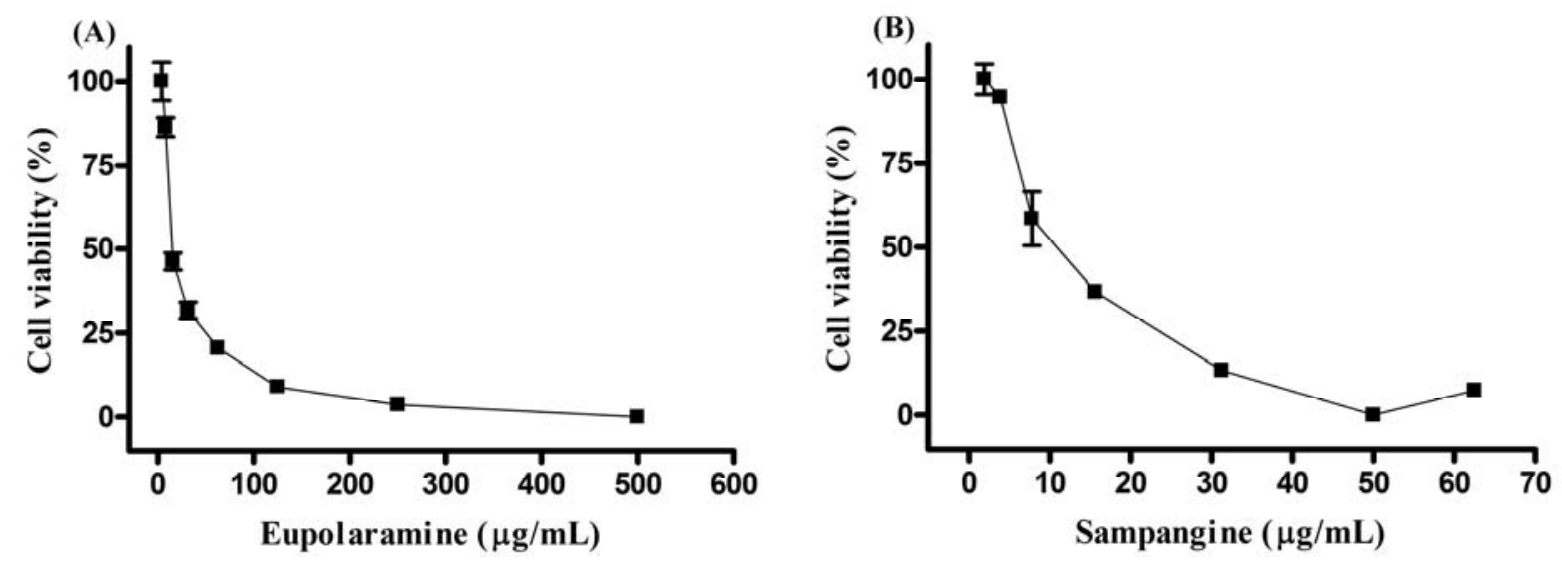

\section{Experimental}

\subsection{General}

The mass spectra were obtained in positive ion mode through the $(+)$ electrospray technique using a Bruker Microtof II high resolution mass spectrometer. The ${ }^{1} \mathrm{H}$ and ${ }^{13} \mathrm{C} 1 \mathrm{D}$ and $2 \mathrm{D}$ NMR experiments were recorded on a Varian-NMR-System $500\left[500 \mathrm{MHz}\left({ }^{1} \mathrm{H}\right)\right.$ and $\left.125 \mathrm{MHz}\left({ }^{13} \mathrm{C}\right)\right] . \mathrm{CDCl}_{3}$ was the solvent used for all of the NMR experiments and the solvent peaks were used to calibrate the equipment. For column chromatography, Merck 60 silica gel $(0,063-0,200 \mathrm{~mm})$ was used. For the 
preparative and analytical TLC $60 \mathrm{PF}_{254}$ ART 7749 silica gel (Merck) was used. The compounds in analysis were observed through the use of UV light (254 e 366) and after spraying with Dragendorff's reagent.

\subsection{Plant material}

The stem bark of Anaxagorea dolichocarpa was collected in the city of Santa Rita, State of Paraíba, Brazil, in February 2006. It was identified by Prof. Maria de Fátima Agra from the Botany Laboratory of the Federal University of Paraiba. A voucher specimen was deposited at the Herbarium Prof. Lauro Pires Xavier (JPB), of the Federal University of Paraiba, with the number Agra \& Góes 5543.

\subsection{Extraction and isolation procedures}

The dried and pulverized stem bark $(2,000 \mathrm{~g})$ was subjected to maceration with $95 \% \mathrm{EtOH}(3 \times 5 \mathrm{~L})$ for 72 hours at room temperature. The EtOH solution was concentrated under vacuum, yielding $64 \mathrm{~g}$ of crude EtOH extract (CEE), which was suspended in $\mathrm{MeOH}-\mathrm{H}_{2} \mathrm{O}$ (3:7) and partitioned with hexane (3,000 mL), $\mathrm{CHCl}_{3}(1,500 \mathrm{~mL})$ and ethyl acetate $(1,500 \mathrm{~mL})$. After removal of the solvents the $\mathrm{CHCl}_{3}$ $(14.0 \mathrm{~g})$ and hexane $(11.0 \mathrm{~g})$ extracts were subjected to column chromatography over silica gel using hexane, $\mathrm{CHCl}_{3}$ and $\mathrm{MeOH}$, either pure or in binary mixtures. Thus, from the $\mathrm{CHCl}_{3}$ extract column 183 fractions were obtained, which were analyzed by analytical TLC and combined according to their chromatographic profiles into 23 groups. The group represented by fractions 12-24 was further purified by silica gel preparative TLC, using dichloromethane-acetonitrile (97:3) as eluent [12], yielding compound 1 (0.023 g). Similarly, from the hexane extract column 277 fractions were obtained and combined into 22 groups. The groups represented by the fractions 135-148 and 198-205 were purified by silica gel preparative TLC using as eluents pure $\mathrm{CHCl}_{3}$ and $\mathrm{CHCl}_{3}-\mathrm{MeOH}$, (99:1), respectively, to yield compounds $2(0.020 \mathrm{~g})$ and $\mathbf{3}(0.010 \mathrm{~g})$.

Eupolauramine (1): Orange crystals. Mp 190-193 ${ }^{\circ} \mathrm{C}$ (lit. [19] Mp 191-192.5 ${ }^{\circ} \mathrm{C}$ ). HRMS $\mathrm{m} / \mathrm{z}$ $288.2845[\mathrm{M}+\mathrm{Na}]^{+}\left(\mathrm{C}_{16} \mathrm{H}_{12} \mathrm{~N}_{2} \mathrm{O}_{2} \mathrm{Na}\right) .{ }^{1} \mathrm{H}-\mathrm{NMR}: \delta_{\mathrm{H}} 3.73$ (s, MeN-5), 4.06 (s, MeO-6), 7.67 (ddd, $J=8.5,7.5$ and $1.5 \mathrm{~Hz}, \mathrm{H}-9), 7.74(\mathrm{ddd}, J=8.8,7.0$ and $1.5 \mathrm{~Hz}, \mathrm{H}-8), 7.90$ (d, $J=4.5 \mathrm{~Hz}, \mathrm{H}-3), 8.13$ (dd, $J=8.0$ and $0.5 \mathrm{~Hz}, \mathrm{H}-7), 9.00(\mathrm{dd}, J=8.5$ and $1.0 \mathrm{~Hz}, \mathrm{H}-10), 9.15(\mathrm{~d}, J=4.5 \mathrm{~Hz}, \mathrm{H}-2) .{ }^{13} \mathrm{C}-\mathrm{NMR}$ : $\delta_{\mathrm{C}} 28.4(\mathrm{MeN}-5), 63.4(\mathrm{MeO}-6), 117.1$ (C-3), 122.6 (C-10c), 122.7 (C-7), 124.2 (C-10), 124.9 (C-5a), 126.6 (C-9), 129.3 (C-8), 130.0 (C-10a), 132.5 (C-6a), 133.1 (C-3a), 137.7 (C-6), 142.9 (C-10b), 150.4 (C-2), 167.0 (C-4). HMBC: H-2/C-3, C-3a, C-4, C-10b; H-3/C-2, C-4, C-10c; H-7/C-6, C-9, C-10a; H-8/C-6a, C-7, C-10; H-9/C-7, C-10, C-10a; H-10/C-6a, C-8, C-10b; MeO-6/C-6; MeN-5/C-4, C-5a. COSY: H-2/H-3, H-7/H-8, H-9/H-10.

Sampangine (2): Yellow crystals. Mp 212-215 ${ }^{\circ} \mathrm{C}$ (lit. [16] Mp 215-217 ${ }^{\circ} \mathrm{C}$ ). HRMS $\mathrm{m} / \mathrm{z} 255.0495$ $[\mathrm{M}+\mathrm{Na}]^{+}\left(\mathrm{C}_{15} \mathrm{H}_{8} \mathrm{~N}_{2} \mathrm{ONa}\right) .{ }^{1} \mathrm{H}-\mathrm{NMR}: \delta_{\mathrm{H}} 7.68(\mathrm{ddd}, J=8.0,8.5$ and $1.0 \mathrm{~Hz}, \mathrm{H}-9), 7.71(\mathrm{~d}, J=6.0 \mathrm{~Hz}$, H-3), 7.82 (ddd, $J=8.0,8.5$ and $1.5 \mathrm{~Hz}, \mathrm{H}-10), 7.91$ (d, $J=5.5 \mathrm{~Hz}, \mathrm{H}-4), 8.45$ (dd, $J=7.5$ and $1.0 \mathrm{~Hz}$, H-8), $8.82(\mathrm{dd}, J=8.0$ and $0.5 \mathrm{~Hz}, \mathrm{H}-11), 8.88$ (d, $J=6.0 \mathrm{~Hz}, \mathrm{H}-2), 9.12(\mathrm{~d}, J=5.5 \mathrm{~Hz}, \mathrm{H}-5)$. ${ }^{13} \mathrm{C}-\mathrm{NMR}: \delta_{\mathrm{C}} 119.1(\mathrm{C}-3), 119.8$ (C-11c), 123.5 (C-4), 125.4 (C-11), 128.5 (C-8), 131.4 (C-9), 132.4 (C-7a), 134.7 (C-10), 135.5 (C-11a), 138.7 (C-3a), 147.4 (C-2), 148.0 (C-6a), 148.5 (C-5), 151.3 
(C-11b), 182.0 (C-7). HMBC: H-2/C-3c, C-3a, C-11b; H-3/C-2, C-4, C-11c; H-4/C-3, C-5, C-11c; H-5/C-3a, C-4, C-6a; H-8/C-10, C-11a; H-9/C-7a, C-11; H-10/C-8, C-11a; H-11/C-7a, C-9. COSY: H-2/H-3, H-4/H-5, H-8/H-9, H-9/H-8,H-10; H-10/H-9,H-11; H-11/H-10.

Imbiline 1 (3): Red crystals. Mp 215-217 ${ }^{\circ} \mathrm{C}$ (lit. [20] Mp 212-214 ${ }^{\circ} \mathrm{C}$ ). ${ }^{1} \mathrm{H}-\mathrm{NMR}$ : $\delta_{\mathrm{H}} 3.95$ (s, MeN-6), 4.00 (s, MeO-7), 7.77 (ddd, $J=8.0,7.0$ and 1.0 Hz, H-10), 7.81 (ddd, $J=8.5,7.5$ and 1.5 Hz, H-9), $8.23(\mathrm{dd}, J=9.5$ and 1,5 Hz, H-8), 8.27 (d, $J=4.5 \mathrm{~Hz}, \mathrm{H}-3), 9.21$ (d, $J=1.5 \mathrm{~Hz}, \mathrm{H}-11), 9.23$ (d, $J=5.5 \mathrm{~Hz}, \mathrm{H}-2) .{ }^{13} \mathrm{C}-\mathrm{NMR}: \delta_{\mathrm{C}} 35.9(\mathrm{MeN}-6), 63.0(\mathrm{MeO}-7), 118.3$ (C-11c), 119.3 (C-3), 122.6 (C-6a), 122.8 (C-8), 125.2 (C-11), 128.5 (C-10), 129.7 (C-11a), 130.4 (C-9), 130.7 (C-7a), 132.3 (C-3a), 144.9 (C-7), 145.1 (C-11b), 148.2 (C-2), 157.6 (C-5), 176.5 (C-4). HMBC: H-2/C-3, C-3a, C-11b; H-3/C-2, C-11c; H-8/C-7, C-9, C-10, C-11a; H-9/C-7a, C-11; H-10/C-8, C-9, C-11a; H-11/C-7a, C-9, C-11b. COSY: H-2/H-3, H-8/H-9, H-10/H-11.

\subsection{Evaluation of "in vitro" antitumor activity}

The human leukemic strain K562 (Chronic Myeloid Leukemia) was cultivated in a RPMI-1640 (Nutricell@) media supplemented with $2 \mathrm{~g} / \mathrm{L} \mathrm{NaHCO}_{3}$ (Sigma-Aldrich), $2 \mathrm{mM}$ L-glutamine (Nutricell@), $100 \mathrm{UI} / \mathrm{mL}$ of penicillin, $100 \mu \mathrm{g} / \mathrm{mL}$ de streptomycin (Sigma-Aldrich) and 10\% bovine fetal serum (Nutricell). The K562 cells $\left(3 \times 10^{5}\right.$ cell $\left./ \mathrm{mL}\right)$ were arranged in 96 wells with different concentrations $(0-500 \mu \mathrm{g} / \mathrm{mL})$ of eupolauramine and sampangine and incubated at $37{ }^{\circ} \mathrm{C}$ and $5 \% \mathrm{CO}_{2}$ for $72 \mathrm{~h}$. The compounds were initially dissolved in dimethylsulfoxide (DMSO) and afterwards complemented with the media. The final DMSO concentration was $0.5 \%$. The cytotoxity was evaluated through the MTT reduction assay, which determines the number of living cells able to reduce the yellow dye 3-(4,5-dimethyl-2-thiazolyl)-2,5-diphenyl-2H-tetrazolium bromide (MTT) to formazan, which has a purple color [26]. In brief, $0.01 \mathrm{~mL}$ of the media was added to each well. After incubating for 4 hours, formazan was dissolved in $0.1 \mathrm{~mL}$ of EtOH under agitation over a microplate shaker for 10 minutes. Afterwards absorbance was read at $595 \mathrm{~nm}$ with the use of a microplate reader (Bio-Rad ${ }^{\circledR}$ Berkeley, CA, USA) for the determination of the $50 \%$ inhibition concentration for cell growth $\left(\mathrm{IC}_{50}\right)$.

\section{Conclusions}

Three azaphenanthrene alkaloids were isolated from the stem bark of A. dolichocarpa. Both sampangine and imbiline 1 are being reported for the first time in the genus Anaxagorea and eupolauramine for the first time in the family Annonaceae. These data contribute to the chemotaxonomy of Annonaceae, and especially for the genus Anaxagorea. The alkaloids eupolauramine and sampangine demonstrated antitumor activity against human cells strain $\mathrm{K} 569$ showing $\mathrm{IC}_{50}$ values of 18.97 (17.06-21.10) $\mu \mathrm{g} / \mathrm{mL}$ and $10.95(10.15-11.80) \mu \mathrm{g} / \mathrm{mL}$, respectively. The interesting antitumoral activities of these alkaloids suggests great potential in the ongoing search for molecules with activity against cancer. 


\section{Acknowledgements}

The authors want to express their gratitude to CNPq, CAPES and FAPESQ-PB/PRONEX for financial support and to Vicente Carlos de Oliveira Costa for obtaining the NMR spectra.

\section{References}

1. Chatrou, L.W.; Rainer, H.; Maas, P.J.M. Annonaceae (Soursop Family). In Flowering Plants of Neotropics; Smith, N., Mori, S.A., Henderson, A., Stevenson, D.W., Heald, S.V., Eds.; Botanical Garden: New York, NY, USA, 2004; pp. 18-20.

2. Champy, P.; Guérineau, V.; Laprévote, O. MALDI-TOF MS profiling of Annonaceous acetogenins in Annona muricata products for human. Molecules 2009, 14, 5235-5246.

3. Melot, A.; Fall, D.; Gleye, C.; Champy, P. Apolar Annonaceous acetogenins from the fruit pulp of Annona muricata. Molecules 2009, 14, 4387-4395.

4. Fechine, I.M.; Vanessa, R.; Navarro, V.R.; Cunha, E.V.L.; Silva, M.S.; Maia, J.G.S.; Barbosa-Filho, J.M. Alkaloids and volatile constituents from Duguetia flagellaris. Biochem. Syst. Ecol. 2002, 30, 267-269.

5. Alias, A.; Hazni, H.; Jaafar, F.M.; Awang, K.; Ismail, N.H. Alkaloids from Fissistigma latifolium (Dunal) Merr. Molecules 2010, 15, 4583-4588.

6. Tavares, J.F.; Silva, M.V.B.; Queiroga, K.F.; Diniz, M.F.F.M.; Barbosa-Filho, J.M.; Haun, M.; Melo, P.S.; Silva, M.S. Xylodiol, a new atisane diterpenoid from Xylopia langsdorffiana St.-Hil. \& Tul. (Annonaceae). Z. Naturforsch. 2007, 62b, 742-744.

7. Cavé, A.; Leboeuf, M.; Waterman, P.G. The aporphinoid alkaloids of the Annonaceae. In Alkaloids: Chemical and Biological Perspectives; Pelletier, S.W., Ed.; Wiley: New York, NY, USA, 1987; Volume 5, pp. 134-270.

8. Maas, P.J.M.; Westra, L.Y.T. Studies in Annonaceae II. A monograph of the genus Anaxagorea A. St. Hil. Part 2. Bot. Jahrb. Syst. 1985, 105, 145-204.

9. Diaz, A.M.P. Neolignans from Anaxagorea clavata. Phytochemistry 1997, 44, 345-346.

10. Gonda, R.; Takeda, T.; Akiyama, T. Studies on the constituents of Anaxagorea luzonensis A. Gray III. Nat. Med. 2002, 56, 10-12

11. Gonda, R.; Takeda, T.; Akiyama, T. Studies on the constituents of Anaxagorea luzonensis A. Gray. Chem. Pharm. Bull. 2000, 48, 1219-1222.

12. Hocquemiller, R.; Rasamizafy, S.; Moretti, C.; Jacquemin, H.; Cavé, A. Anaxagoreine, a new alkaloid isolated from two species of the genus Anaxagorea. Planta Med. 1981, 41, 48-50.

13. Lobão, A.Q.; Araújo, D.S.D.; Kurtz, B.C. Annonaceae das restingas do estado do Rio de Janeiro, Brasil. Rodriguésia 2005, 56, 85-96.

14. Andrade, E.H.A.; Oliveira, J.; Zoghbi, M.G. Volatiles of Anaxagorea dolichocarpa Spreng. \& Sandw. and Annona densicoma Mart. growing wild in the state of Pará, Brazil. Flavour Frag. J. 2007, 22, 158-160.

15. Chiappeta, A.D.A.; Mello, J.F. Higher plants with biological activity: Plants of Pernambuco. Rev. Inst. Antibiot. UFPE 1984, 11, 99-111. 
16. Muhammad, I.; Dunbar, D.C.; Takamatsu, S.; Walker, L.A.; Clark, A.M. Antimalarial, cytotoxic and antifungal alkaloids from Duguetia hadrantha. J. Nat. Prod. 2001, 64, 559-562.

17. Rys, A.; Couture, A.; Deniau, E.; Lebrun, S.; Grandclaudon, P. A brief total synthesis of eupolauramine. Synlett 2004, 12, 2233-2235.

18. Orabi, K.Y.; Li, E.; Clark, A.M.; Huffird, C.D. Microbial transformation of sampangine. J. Nat. Prod. 1999, 62, 988-992.

19. Kitahara, Y.; Mochii, M.; Mori, M.; Kubo, A. Synthetic studies of imbiline 1, a constituent of Eupomatia species. Tetrahedron 2003, 59, 2885-2891.

20. Carroll, A.R.; Taylor, W.C. Constituents of Eupomatia species. XII. Isolation of constituents of the tubers and aerial parts of Eupomatia bennettii and determination of the structures of new alkaloids from the aerial parts of E. bennettii and minor alkaloids of E. laurina. Aust. J. Chem. 1991, 44, 1615-1626.

21. Agarwal, A.K.; Xu, T.; Jacob, M.R.; Feng, Q.; Lorenz, M.C.; Walker, L.A.; Clark, A.M. Role of Heme in the antifungal activity of the azaoxoaporphine alkaloids sampangine. Eukaryot. Cell 2008, 7, 387-400.

22. Peterson, J.R.; Zjawiony, J.K.; Liu, S.; Hufford, C.D.; Clark, A.M.; Rogers, R.D. Copyrine alkaloids: Synthesis, spectroscopic characterization, and antimycotic/antimycobacterial activity of A- and B-ring-functionalized sampangines. J. Med. Chem. 1992, 35, 4069-4077.

23. Kluza, J.; Clark, A.M.; Bailly, C. Apoptosis induced by the alkaloid sampangine in HL-60 leukemia cells: Correlation between the effects on the cell cycle progression and changes of mitochondrial potential. Ann. N. Y. Acad. Sci. 2003, 1010, 331-334.

24. Costa-Lotufo, L.V.; Khan, M.T.H.; Ather, A.; Wilke, D.V.; Jimenez, P.C.; Pessoa, C.; Moraes, M.E.A.; Moraes, M.O. Studies of the anticancer potential of plants used in Bangladeshi folk medicine. J. Ethnopharmacol. 2005, 99, 21-30.

25. Bezerra, D.P.; De Castro, F.O.; Alves, A.P.; Pessoa, C.; De Moraes, M.O.; Silveira, E.R.; Lima, M.A.; Elmiro, F.J.; De Alencar, N.M.; Mesquita, R.O.; Lima, M.W.; Costa-Lotufo, L.V. In vitro and in vivo antitumor effect of 5-FU combined with piplartine and piperine. J. Appl. Toxicol. 2008, 28, 156-163.

26. Mosmann, T. Rapid colorimetric assay for cellular growth and survival: Application to proliferation and cytotoxicity assays. J. Immunol. Methods 1983, 65, 55-63.

Sample Availability: Samples of the compounds 1-3 are available from the authors.

(C) 2011 by the authors; licensee MDPI, Basel, Switzerland. This article is an open access article distributed under the terms and conditions of the Creative Commons Attribution license (http://creativecommons.org/licenses/by/3.0/). 